\title{
Spread of viruses in garlic fields cultivated under different agricultural production systems in Brazil
}

\author{
Michelle de S. Fayad-André1, André Nepomuceno Dusi² \& Renato Oliveira Resende ${ }^{3}$ \\ ${ }^{1}$ Departamento de Fitopatologia, Universidade de Brasília, 70919-970, Brasília, DF, Brazil; ${ }^{2}$ Secretaria de Assuntos \\ Internacionais, Embrapa, 70770-901, Brasília, DF, Brazil; ${ }^{3}$ Departamento de Biologia Celular, Universidade de Brasília, \\ 70919-900, Brasília, DF, Brazil
}

Author for correspondence: Renato Oliveira Resende, e-mail: rresende@unb.br

\begin{abstract}
Samples from four regions, representing $76 \%$ of the garlic growing area in Brazil, were tested by RT-PCR for the presence of Onion yellow dwarf virus (OYDV), Leek yellow stripe virus (LYSV), Garlic common latent virus (GCLV), Garlic virus C (GarV-C), Garlic virus D (GarV-D) and Garlic mite-borne filamentous virus (GarMbFV). The samples (352 bulbs) represented five agricultural systems: traditional common garlic (CG), virus-free common garlic (VFCG), non-vernalized noble garlic (NVNGSG) and vernalized noble garlic cultivated by small growers (VNGSG), and vernalized noble garlic adopted by major growers (VNGMG). Multiple infections were detected in $22 \%$ of the samples. Potyvirus species were present in all regions. LYSV prevailed over OYDV while the carlavirus GCLV was less prevalent. GarV-C and GarMbFV were the most prevalent among the allexivirus species. The NVNG production system had a higher prevalence of LYSV and GarV-C. The CG production system, that uses less technology, had the highest prevalence for all species, especially LYSV that prevailed in $94 \%$ of the samples. Overall, the regions with higher technological input employing better quality seeds had the lowest viral prevalence for all species. This monitoring provides information to establish a strategy to raise the phytosanitary quality and the national productivity of garlic.
\end{abstract}

Key words: Allium sativum, diseases, occurrence, production system, RT-PCR, viruses.

\section{RESUMO}

Disseminação de vírus em campos de alho cultivado em diferentes sistemas de produção no Brasil

Amostras de quatro regiões produtoras que representam aproximadamente $76 \%$ da área de alho plantada no Brasil, foram testadas por RT-PCR para a presença de Onion yellow dwarf virus (OYDV), Leek yellow stripe virus (LYSV), Garlic common latent virus (GCLV), Garlic virus C (Garv-C), Garlic virus D (Garv-D) e Garlic mite-borne filamentous virus (GarMbFV). As amostras (352 bulbos) foram provenientes de cinco sistemas de cultivo: alho tradicional comum (CG), alho tradicional livre de vírus (VFCG), alho nobre nãovernalizado (NVNGSG) e alho nobre vernalizado cultivado por pequenos produtores (VNGSG), e alho nobre vernalizado utilizado por grandes produtores (VNGMG). Infecções múltiplas foram detectadas em $22 \%$ das amostras. As espécies de potyvírus foram observadas em todas as regiões. O LYSV prevaleceu sobre OYDV enquanto o carlavírus, GCLV foi o menos disseminado. Garv-C e GarMbFV foram as mais prevalentes entre os allexivírus. O sistema de produção NVNGSG teve uma maior prevalência de LYSV e Garv-C. O sistema de produção CG apresentou a maior prevalência de todas as espécies, especialmente LYSV (94\% das amostras). As regiões com maior nível tecnológico tiveram a menor prevalência viral. As informações deste monitoramento, poderão auxiliar no estabelecimento de estratégias visando o aumento da qualidade fitosanitária e da produtividade nacional do alho.

Palavras-chave: Allium sativum, doenças, ocorrência, RT-PCR, sistema de produção, viroses.

\section{INTRODUCTION}

Garlic is the fifth most economically important vegetable in Brazil (IBGE, 2009) and is cultivated in all geographical areas except for the North region of the country.

As the crop is vegetatively propagated, virus infections are transmitted from one crop cycle to another through infected cloves. There are more than 12 virus species infecting garlic in the world (van Dijk, 1993; Sumi et al., 1993; Yamashita et al., 1996). In Brazil, so far, seven virus species were reported infecting garlic, belonging to the Potyvirus, Carlavirus and Allexivirus genera (Fajardo et al., 2001; Melo-Filho et al., 2006; Mituti, 2011). Most of them are found in a virus complex of more than one virus species. Viruses of the genus Potyvirus are the major cause of losses in the garlic crop and these losses are even more pronounced when plants are mixed infected with Carlavirus or Allexivirus species (Takaichi et al., 2001).

Virus surveys of Brazilian growing areas have been conducted since the 1970's (Dusi, 1995; Fajardo et al., 2001; Melo-Filho et al., 2004; Mituti, 2011). The serological techniques used until the end of the 1990's were limited and therefore did not allow an accurate identification of the different species. After the advent of molecular biology, virus species were allocated to new taxonomic groups. 
Species of Allexivirus, Potyvirus and Carlavirus were detected in the central region of Brazil with the aid of more accurate diagnostic techniques fit to the current taxonomic status of garlic viruses (Fajardo et al., 2001 \& Melo-Filho et al., 2004; Mituti, 2011).

In Brazil, two types of garlic are commercialized. The common garlic, cultivated in the Central and Northeast regions of the country, requires a shorter cold period and is not affected by the day length for bulbification. These cultivars produce several bulbs with small cloves and have lower commercial value. The other type is the noble garlic that is mainly grown in the South region and is dependent of cold temperatures and long day length for bulbification. Alternatively, noble garlic can also be cultivated in the Central regions after vernalization to induce bulb production. These cultivars produce less bulbs with large cloves reaching higher commercial value.

Common and noble garlic cultivars are basically grown under four agricultural cultivation systems: 1) Common garlic is cultivated mainly in warmer regions of the country by small farmers with low technological input. These cultivars can be grown from two types of seeds: traditional common garlic seeds (CG) and, presently in a small scale, virus-free common garlic seeds (VFCG); 2) Non-vernalized noble garlic cultivars are cultivated by small farmers in the Southern region, also with low technological input (NVNGSG); 3) Vernalized noble garlic used by small growers in the Northeastern region depends on vernalization to induce bulb formation when grown in short day length areas (VNGSG); and 4) Vernalized noble garlic cultivated by major growers in the Brazilian Cerrado, using high techological input, including vernalization to induce bulbification (VNGMG).

Since growers use distinct levels of technology and seeds with a highly variable quality, large differences in virus species distribution and virus infection rates under these four major cultivation systems are expected. However, so far, a systematic survey on the distribution of these six species at a national level has never been reported. The aim of this study was to determine the occurrence and the prevalence of six species of the garlic virus complex (Onion yellow dwarf virus, OYDV; Leek yellow stripe virus, LYSV; Garlic common latent virus, GCLV; Garlic virus C, GarV-C; Garlic virus D, GarV-D; and Garlic mite-borne filamentous virus, GarMbFV) reported to occur in Brazil in the main growing regions cultivated under different agricultural production systems using species-specific PCR technique. SLV was not included in this survey since it was reported in 2010, after this survey was completed (Mituti, 2011).

\section{MATERIALS AND METHODS}

\section{Synthesis and efficiency of species-specific primers \\ Six pairs of specific primers denoted OYDV sense (5' CCA TGG CAG GAG ATG GGG AGG ACG C3'), OYDV}

antisense (5' CCA TGG ACA TTC TAA TAC CAA GCA ACG 3'), LYSV sense (5' CCA TGG CCG GCG ACG AAC TAG ATG C 3'), LYSV antisense (5' CCA TGG ACT GCA TAT GCG CAC CAT C 3'), GarCLV sense (5' CCA TGG CAG TGA GTG AAA CAG AGG 3'), GarCLV antisense (5' CCA TGG AGT CTG CAT TGT TGG ATC C 3'), GarV-C sense (5' CCA TGG GTG GAG ACA GCC TAT CTG 3'), GarV-C antisense (5' CCA TGG AAA ACG TTA ACA TGA GAG GC 3'), GarV-D sense (5' CCA TGG ATG AAC AAG GAA ACA CG 3'), GarV-D antisense (5' CCA TGG AGA ATG TGA TCA TTG GAG G 3'), GarMbFV sense (5' CCA TGG ACG ACC CTG TTG ACC CAA 3') and GarMbFV antisense (5' CCA TGG AGA ACG TAA TCA TGG GAG G 3') were synthesized from the sequence of the coat protein (CP), one for each of the six selected virus species. The specificity of the oligonucleotides to amplify the CP genes of OYDV, LYSV, GarCLV, GarV-C, GarV-D and GarMbFV was tested by RTPCR. The expected sizes of the OYDV, LYSV, GarCLV, GarV-C, GarV-D and GarMbFV amplified PCR products were 774 bp, 879 bp, 960 bp, 780 bp, 753 bp and 762 bp, respectively. Approximately $50 \mathrm{ng}$ of purified plasmid DNA containing the coat protein gene of each viral species were incubated with $10 \mathrm{mM}$ each specific sense and antisense primers, $100 \mu \mathrm{M}$ each dNTP, 10x PCR buffer, $50 \mathrm{mM}$ magnesium chloride $\left(\mathrm{MgCl}_{2}\right), 5 \mathrm{U}$ of Taq DNA Polymerase adding up to a $50 \mu \mathrm{L}$ volume with water. The reaction was processed in an ESCO Thermocycler (Swift Maxi model). Denaturation was performed for $3 \mathrm{~min}$ at $94^{\circ} \mathrm{C}$, followed by 30 cycles of amplification $\left(94^{\circ} \mathrm{C} / 1\right.$ $\min , 48^{\circ} \mathrm{C} / 1 \mathrm{~min}$ and $30 \mathrm{~s}, 72^{\circ} \mathrm{C} / 1 \mathrm{~min}$ ) and a final cycle of $7 \mathrm{~min}$ at $72^{\circ} \mathrm{C}$. The amplified products and the marker ( $1 \mathrm{~kb}$ ladder) were applied in an agarose gel $(1 \%)$, subjected to electrophoresis at $80 \mathrm{~V}$ and visualized under UV light on the Alpha Innotech equipment.

\section{Sampling of garlic from growing regions}

Garlic samples from four regions of Brazil were requested from garlic growers by the second author. Growers from the states of Goiás, Bahia, Rio Grande do Sul and Minas Gerais were contacted.

Samples with eight to twelve bulbs were received from farmers from nine municipalities (Table 1) in the years 2008 and 2009. The received samples were identified by production system, geographic area, property owner and cultivar (Table 1). In total, 352 garlic bulbs were received from 37 properties and then classified according the five cropping systems (CG, VFCG, NVNGSG, VNGSG, VNGMG). The bulbs of each lot were threshed and the cloves counted. A subsample of $10 \%$ of the cloves of each lot were planted in polystyrene trays with the substrate Plantimax (one clove per cell) in a greenhouse at the Experimental Station of the Universidade de Brasília. The plants were transplanted to 21 pots and kept under greenhouse conditions. Ten days later, the middle third of the most developed leaf of each 
Spread of virus species in garlic fields cultivated under different agricultural production...

TABLE 1 - Description of the analyzed garlic samples regarding their geographical origin, production system and cultivar

\begin{tabular}{|c|c|c|c|c|c|}
\hline District & State & Production system & Cultivar & $\begin{array}{c}\text { Sample } \\
\text { code }\end{array}$ & Property/Owner \\
\hline Cristalina & GO & & Ito & GO1 & Rio Preto Farm \\
\hline Cristalina & GO & & Chonan & $\mathrm{GO} 2$ & Santa Bárbara Farm \\
\hline Cristalina & GO & & Ito & GO3 & Lírio Farm \\
\hline Cristalina & GO & $\mathrm{VNGMG}^{1}$ & Caçador & GO4 & Rio Preto Farm \\
\hline Cristalina & GO & & Jonas & GO5 & Lírio Farm \\
\hline Cristalina & GO & & Quitéria & GO6 & Lírio Farm \\
\hline Cristalina & GO & & Caçador & GO7 & Lírio Farm \\
\hline Cristalina & GO & & Chonan & GO8 & Lírio Farm \\
\hline Cristopólis & BA & CG & Cateto Roxo & BA30 & Hermenegildo Farm \\
\hline Taquarendi/Mirangaba & BA & VFCG & Amarante & BA10 & Faz. Mandacaru Farm \\
\hline Caatinga do Moura/Jacobina & BA & VFCG & Amarante & BA12 & Boa Vista Farm \\
\hline Taquarendi/Mirangaba & BA & VFCG & Amarante & BA13 & Faz. Mandacaru Farm \\
\hline Taquarendi/Mirangaba & BA & VFCG & Amarante & BA25 & Faz. Mandacaru Farm \\
\hline Taquarendi/Mirangaba & $\mathrm{BA}$ & VFCG & Caçador & BA09 & Faz. Mandacaru Farm \\
\hline Taquarendi/Mirangaba & BA & VFCG & Cateto Roxo & BA11 & Faz. Caetano Farm \\
\hline Boninal & BA & VFCG & Cateto Roxo & BA26 & CEO community \\
\hline Oliveira dos Brejinhos & $\mathrm{BA}$ & VFCG & Cateto Roxo & BA28 & Boa Esperança Farm \\
\hline Cristopólis & BA & VFCG & Cateto Roxo & BA29 & Cerquinha Farm \\
\hline Taquarendi/Mirangaba & $\mathrm{BA}$ & VFCG & Cateto Roxo & BA31 & Faz. Canavieira Farm \\
\hline Caatinga do Moura/Jacobina & $\mathrm{BA}$ & VNGSG & Caçador & BA14 & Olhos D’Água Farm \\
\hline Taquarendi/Mirangaba & BA & VNGSG & Caçador & BA27 & Canavieira Farm \\
\hline Flores da Cunha & $\mathrm{RS}$ & NVNGSG & $\mathrm{ni}^{2}$ & $\mathrm{RS} 15$ & Owner Agenor \\
\hline Flores da Cunha & $\mathrm{RS}$ & NVNGSG & Quitéria & RS16 & Owner Marcelo \\
\hline Flores da Cunha & $\mathrm{RS}$ & NVNGSG & Chonan & RS17 & Owner Rafael Carlin \\
\hline Flores da Cunha & RS & NVNGSG & Caçador & RS18 & Owner Orildo \\
\hline Flores da Cunha & $\mathrm{RS}$ & VFCG & ni & RS20 & Owner Márcio Slavieiro \\
\hline Francisco Sá & MG & $\mathrm{CG}$ & Cateto Roxo & MG21 & Traçadal Farm \\
\hline Francisco Sá & MG & VFCG & Cateto Roxo & MG19 & Tábuas Farm \\
\hline Francisco Sá & MG & VFCG & Cateto Roxo (Field) & MG23 & Gameleira Farm \\
\hline Francisco Sá & MG & VFCG & Cateto Roxo (Greenhouse) & MG22 & Gameleira Farm \\
\hline São Gotardo & MG & VNGMG & Ito & MG38 & Sekita Agribusiness \\
\hline São Gotardo & MG & VNGMG & Ito & MG40 & Jorge Fukuda \\
\hline São Gortardo & MG & VNGMG & Ito Sul & MG35 & Sekita Agribusiness \\
\hline São Gotardo & MG & VNGMG & Ito Supremo & MG36 & Sekita Agribusiness \\
\hline São Gotardo & MG & VNGMG & Ito Supremo & MG37 & Suguiana \\
\hline São Gotardo & MG & VNGMG & São Valentino & MG39 & Jorge Fukuda \\
\hline Francisco Sá & MG & VNGSG & Caçador & MG24 & Emater \\
\hline
\end{tabular}

${ }^{1}$ VNGMG, Vernalized Noble Garlic Major Grower; VNGSG, Vernalized Noble Garlic Small Grower; NVNGSG, Non-Vernalized Noble Garlic Small Grower; VFCG, Virus-Free Common Garlic; CG, Traditional Common Garlic. ${ }^{2}$ not informed.

plant was collected and stored in liquid nitrogen. Then, they were taken to the laboratory and stored at $-80^{\circ} \mathrm{C}$ for PCR analysis.

Virus free samples were obtained from Embrapa Hortaliças that derived from its virus free garlic seed program. These virus free cloves were produced under greenhouse conditions and were previously indexed by electron microscopy and serology so they could be used as an uninfected control. These samples were processed as described for the field samples.

\section{RNA extraction and viral cDNA synthesis}

Samples of $150 \mathrm{mg}$ of leaves were triturated in liquid nitrogen and the total RNA was extracted with $500 \mu \mathrm{L}$ of Plant Extraction Reagent (Invitrogen) at room temperature. The samples were centrifuged at $21,000 \mathrm{~g}$ for $2 \mathrm{~min}$ at $25^{\circ} \mathrm{C}$ and the supernatant was collected and transferred to a new eppendorf tube. Then, $100 \mu \mathrm{L}$ of $5 \mathrm{M} \mathrm{NaCl}$ and $300 \mu \mathrm{L}$ of chloroform were added to the tube. After homogenization, the centrifugation was repeated and the aqueous phase was collected and the same volume of isopropanol was added to it. The mixture was laid to rest for $10 \mathrm{~min}$ and then centrifuged at $21,000 \mathrm{~g}$ for $10 \mathrm{~min}$ at $4^{\circ} \mathrm{C}$. The supernatant was discarded and the pellet washed with $1 \mathrm{ml}$ of $75 \%$ ethanol and briefly centrifuged. The pellet was raised in $20 \mu \mathrm{L}$ of MilliQ water treated with DEPC. The total RNA was stored at $-80^{\circ} \mathrm{C}$. The reverse transcriptase (RT) reaction was performed according to the protocol of the M-MLV (Moloney murine leukemia virus) reverse transcriptase (Promega), using $10 \mathrm{mM}$ of the specific T1 primer (5' CCT GCA GGA TCC TTA GGT ${ }_{(18)}$ 3', Rodrigues et al., 2001), which anneals to the poly-A tail of the mRNA of all six viruses, and $2 \mu \mathrm{L}$ of the total RNA extracted according to the protocol above. The mixture was incubated at $37^{\circ} \mathrm{C}$ for $60 \mathrm{~min}$. 


\section{Quality of total RNA extraction for the RT-PCR reactions}

Besides the use of positive and negative controls for virus amplification, the primer pair EF1F (5' TGT TGC TGT TAA GGA TTT GAA GCG 3') and EF1R (5' AAC AGT TTG ACG CAT GTC CCT AAC 3') were used to validate the total RNA extraction method. This primer pair amplifies an internal region of the mRNA of a gene that encodes for the elongation factor EF-1 $\alpha$ in plants, corresponding in Passiflora edulis and Glycine max to a fragment of $358 \mathrm{bp}$ (Abreu \& Aragão, 2007; Nunes et al., 2006). A sample of total RNA from plants infected with GarV-C, D-GarV and GarMbFV (BA31) and three negative samples for the six tested species from garlic growers (RS20, MG38 and MG39) were incubated with the primers EF1F and EF1R in order to verify the integrity of the total RNA extracted. The total nucleic acid extracts of tomato (Solanum lycopersicum) and samples of total RNA extracts from a garlic plant proven to be virus-free were used, respectively, as positive and negative controls. The reaction was processed in an ESCO Thermocycler (Swift Maxi model) according to the protocol described in the synthesis of cDNA and RT-PCR with some modifications in the annealing temperature and the number of cycles (denaturation for 3 min at $94^{\circ} \mathrm{C}$, followed by 35 cycles $94^{\circ} \mathrm{C} / 1 \mathrm{~min}, 52^{\circ} \mathrm{C} / 1 \mathrm{~min}$ and $72^{\circ} \mathrm{C} / 1 \mathrm{~min}$ and a final extension of $7 \mathrm{~min}$ at $72^{\circ} \mathrm{C}$ ).

\section{RT-PCR of garlic leaf samples}

Approximately $50 \mathrm{ng}$ of cDNA of each sample were incubated with $10 \mu \mathrm{M}$ of each virus-specific sense and antisense primers, $10 \mathrm{mM}$ dNTP mix, 5x Green Go Taq Reaction Buffer and 1.25 U Go Taq DNA polymerase, adding up to a $25 \mu \mathrm{L}$ volume with water. The reaction was processed in an ESCO Thermocycler (Swift Maxi model). Denaturation was performed for $3 \mathrm{~min}$ at $94^{\circ} \mathrm{C}$, followed by 30 amplification cycles $\left(94^{\circ} \mathrm{C} / 1 \mathrm{~min} ; 60^{\circ} \mathrm{C} / 1 \mathrm{~min} ; 72^{\circ} \mathrm{C} / 1\right.$ min) and a final extension cycle of $7 \mathrm{~min}$ at $72^{\circ} \mathrm{C}$. The plasmids DNA containing the coat protein gene of each viral species and the blank sample (PCR mixture without total RNA extracts) were used, respectively, as positive and negative controls in each set of RT-PCR reactions performed. The amplified products and $1 \mathrm{~Kb}$ DNA Ladder marker (Invitrogen) were applied in an agarose gel $0.8 \%$, diluted in a $0.5 x$ Tris-borate-EDTA (TBE) buffer, subjected to electrophoresis at $120 \mathrm{~V}$, stained with ethidium bromide (0.1mgl-3) and visualized under UV light on the Alpha Innotech equipment.

\section{RESULTS}

\section{Efficiency of species-specific primers}

The coat protein gene of each species was amplified with its specific oligonucleotide pair. The bands obtained had the expected size for the sequence of the coat protein and the amplified fragments were approximately $774 \mathrm{bp}$, $879 \mathrm{bp}, 960 \mathrm{bp}, 780 \mathrm{bp}, 753 \mathrm{bp}$ and $762 \mathrm{bp}$ for OYDV,
LYSV, GCLV, GarV-C, GarV-D and GarMbFV, respectively (data not shown).

\section{RT-PCR from total RNA extracts of plants}

Healthy and infected samples were tested for the quality of RNA extraction prior analyses. The cDNA of total RNA was amplified using a specific pair of primers of an endogenous plant gene. A segment of the mRNA of approximately $358 \mathrm{bp}$ was amplified in all tested samples (data not shown) which corresponds to an internal sequence of a gene conserved as an elongation factor identified in plants. Total RNA was intact (data not shown), ensuring the efficiency of the extraction process and allowing the synthesis of cDNA targets in the subsequent viral detection reaction of the field samples.

\section{Occurrence of species of the virus complex in four garlic growing areas in Brazil}

Samples from all regions were infected with at least three virus species. In the states of Minas Gerais and Bahia, the six tested species were present. In the South region and in Minas Gerais, only two potyvirus species and one allexivirus species were detected (Table 2); and in Goiás all the species studied of the three genera were found except GarV-D.

Potyvirus species are widespread. The only carlavirus detected until 2009 in Brazil (GarCLV) was observed in the samples collected from all the regions. At least one species of allexivirus was detected in all regions. GarV-C occurred in all regions but Garv-D and GarMbFV are limited to the Cerrado region (Table 2).

\section{Prevalence of garlic virus species per production system and garlic growing areas in Brazil}

Data related to the prevalence of the six viral species detected per production system in the different growing areas are presented in Table 2. In general, potyvirus species were prevalent in the five production systems. However, LYSV had a higher prevalence than OYDV, ranging from 0 to $100 \%$ among the sampled localities. The carlaviruses were generally less prevalent than potyviruses or allexiviruses, regardless of the production system. Allexivirus species were detected in all production systems and GarV-C was the most prevalent, especially in CG (93\%) from Cristópolis (BA) and the same happened to GarMbFV in the VFCG system (55\%) from Francisco Sá (MG). Garv-D was found only in the VFCG system (Table 2).

In VNGMG, more specifically in Cristalina (Goiás) municipality, LYSV prevailed over all other viruses and was detected in four of the eight sampled properties (Table 2). In the district of São Gotardo (Minas Gerais), under the same production system, only three species were detected and their rates of prevalence were lower than in other systems.

As for NVNGSG, four viral species were detected. However, there was a prevalence of LYSV (30\%) followed by GarV-C (22\%). Both GarV-D and GarMbFV were not 
Spread of virus species in garlic fields cultivated under different agricultural production...

TABLE 2 - Prevalence of garlic-infecting virus species per agricultural production systems

\begin{tabular}{|c|c|c|c|c|c|c|c|c|}
\hline \multirow[b]{2}{*}{$\begin{array}{l}\text { Production } \\
\text { System }\end{array}$} & \multirow[b]{2}{*}{$\begin{array}{l}\text { Production } \\
\text { Area }\end{array}$} & \multirow[b]{2}{*}{ District } & \multicolumn{6}{|c|}{ Virus Prevalence (\%) } \\
\hline & & & OYDV $^{2}$ & LYSV & GarCLV & GarV-C & GarV-D & GarMbFV \\
\hline $\mathrm{VNGMG}^{1}$ & $\mathrm{GO}$ & Cristalina & 7 & 46 & 7 & 13 & 0 & 10 \\
\hline VNGMG & MG & São Gotardo & 2 & 16 & 0 & 0 & 0 & 2 \\
\hline NVNGSG & $\mathrm{RS}$ & Flores da Cunha & 3 & 30 & 5 & 22 & 0 & 0 \\
\hline VNGSG & BA & Caatinga Moura/Jacobina-BA14 & 0 & 90 & 0 & 0 & 0 & 0 \\
\hline VNGSG & BA & Taquarendi/ Mirangaba-BA09 & 50 & 60 & 0 & 60 & 0 & 0 \\
\hline VNGSG & BA & Taquarendi/ Mirangaba-BA27 & 0 & 100 & 50 & 0 & 0 & 0 \\
\hline VNGSG & MG & Francisco Sá-MG24 & 0 & 100 & 0 & 0 & 0 & 0 \\
\hline VFCG & $\mathrm{BA}$ & Boninal & 63 & 63 & 12 & 0 & 0 & 0 \\
\hline VFCG & BA & Caatinga Moura/Jacobina-BA12 & 50 & 100 & 0 & 0 & 50 & 0 \\
\hline VFCG & BA & Cristopólis-BA29 & 20 & 0 & 0 & 0 & 0 & 0 \\
\hline VFCG & BA & Oliveira dos Brejinhos-BA28 & 0 & 0 & 8 & 58 & 0 & 0 \\
\hline VFCG & BA & Taquarendi/ Mirangaba-BA10 & 0 & 0 & 0 & 0 & 0 & 20 \\
\hline VFCG & BA & Taquarendi/ Mirangaba-BA11 & 20 & 10 & 0 & 0 & 0 & 0 \\
\hline VFCG & BA & Taquarendi/ Mirangaba-BA13 & 14 & 29 & 0 & 0 & 0 & 0 \\
\hline VFCG & $\mathrm{BA}$ & Taquarendi/ Mirangaba-BA25 & 0 & 0 & 0 & 22 & 0 & 11 \\
\hline VFCG & $\mathrm{BA}$ & Taquarendi/ Mirangaba-BA31 & 0 & 0 & 0 & 90 & 40 & 50 \\
\hline VFCG & MG & Francisco Sá-MG22 & 0 & 0 & 0 & 57 & 0 & 43 \\
\hline VFCG & MG & Francisco Sá-MG19 & 0 & 60 & 0 & 50 & 20 & 30 \\
\hline VFCG & MG & Francisco Sá-MG23 & 27 & 18 & 0 & 9 & 0 & 55 \\
\hline $\mathrm{CG}$ & $\mathrm{BA}$ & Cristópolis-BA30 & 0 & 80 & 0 & 93 & 0 & 53 \\
\hline CG & $\mathrm{MG}$ & Francisco Sá-MG21 & 100 & 47 & 47 & 0 & 0 & 47 \\
\hline
\end{tabular}

${ }^{1}$ Vernalized Noble Garlic Major Grower (VNGMG). Vernalized Noble Garlic Small Grower (VNGSG). Non Vernalized Noble Garlic Small Grower (NVNGSG). Virus-Free Common Garlic (VFCG). Traditional Common Garlic (CG). Total: Number of infected samples/total number of samples per production system. ${ }^{2}$ Onion yellow dwarf virus (OYDV), Leek yellow stripe virus (LYSV), Garlic common latent virus (GarCLV), Garlic virus C (GarV-C), Garlic virus D (GarV-D), Garlic mite-borne filamentous virus (GarMbFV).

found in samples from that system. VNGSG had high prevalence rates of LYSV ( $\geq 60 \%)$, the virus was detected in all samples and the prevalence was $100 \%$ in two of them. Half of the samples had multiple infections with OYDV and GarV-C or GarCLV, and LYSV was always the prevailing species. GarV-D and GarMbFV were not detected in the samples from that system.

Potyvirus species had a lower prevalence in VFCG in relation to the other systems. Five out of 12 analyzed samples had no potyviruses detected. However, in the samples BA11 and BA13 only potyvirus species were detected and with a low prevalence $(\leq 29 \%)$. GCLV was detected in only two samples and with low prevalence $(\leq 8 \%)$. At least one allexivirus species was detected in seven out of 12 samples. In samples BA31 and MG19 all allexivirus species were detected and its prevalence exceeded 20\%. Three samples (BA12, MG19 and MG23) had multiple infections with species of the two genera, potyvirus and allexivirus. The BA29 sample had a single infection with OYDV at low prevalence (20\%). In CG all species were detected, except GarV-D. LYSV and GarMbFV were detected in two analyzed samples from this system with prevalence higher than $47 \%$. In the samples BA30 and MG21 GarV-C and OYDV prevailed with rates of $83 \%$ and $100 \%$, respectively.

In the production areas of Bahia (Table 2), at Caatinga do Moura/Jacobina, LYSV prevailed with rates higher than $90 \%$. OYDV varied according to the production system used. At Boninal, potyvirus species prevailed with a rate of $63 \%$, followed by GarCLV (12\%). At Oliveira dos Brejinhos only GarCLV and GarV-C were detected, the last being the prevailing species (58\%). At Cristópolis, in the BA29 sample from VFCG only OYDV was detected and with a low prevalence $(20 \%)$. In contrast, in the BA30 sample it was possible to find LYSV, GarV-C and GarMbFV with prevalence exceeding 50\%.

At Taquarendi/Mirangaba, samples from two production systems were analyzed. In VFCG, four out of five samples presented a virus complex prevalence lower than $29 \%$, except for sample BA31, which had a prevalence of allexivirus species exceeding $40 \%$. However, in VNGSG it was possible to observe the prevalence over $50 \%$, and LYSV stood out for infecting $100 \%$ of sample BA27.

In Minas Gerais (Table 2), at São Gotardo, which uses VNGMG, three viral species were detected, although with low prevalence. LYSV was the prevailing species $(16 \%)$. At Francisco de Sá, potyviruses were the major occurring viruses, with $100 \%$ of prevalence in samples MG24 and MG21, under VNGSG and CG production systems. GarCLV was detected in one out of five samples. At least one allexivirus species was detect in samples from each production system, except in VNGSG. GarV-C and GarMbFV prevailed over GarV-D.

At Flores da Cunha (Rio Grande do Sul) (Table 2), the highest prevalence was for LYSV (above 30\%). GarCLV 
had a low prevalence less than $10 \%$. At least one allexivirus species could be found in this region.

In general, taking into account the different garlic production systems in Brazil, LYSV prevailed over all other species except in VFCG (Table 2). However, in VFCG, in Boninal (Bahia), OYDV and LYSV prevalence rates were equal (63\%). GarCLV prevalence ranged from zero to $12 \%$ in VFCG. The allexivirus species were more prevalent in samples from CG than in other production systems (Table 2).

\section{Prevalence of species of the garlic virus complex per cultivar}

Among the potyvirus species, LYSV prevailed over OYDV in almost all cultivars, regardless of the production system (Table 3). GarCLV occurred in five cultivars at low prevalence rates compared to species of the other genera. In general, allexivirus species were more prevalent in common cultivars (Table 3). GarV-C, GarV-D and GarMbFV prevailed in cv. Caçador, Amarante and Cateto Roxo, respectively. Cultivar Cateto Roxo, produced in both CG and VFCG systems, was the only infected with the six viral species (Table 3 ).

The cultivars Amarante, Caçador, Chonan, Ito, Jonas and Quitéria were infected with at least two virus species. The cultivars Jonas and Quiteria were not infected with allexivirus species and the cv. São Valentino, surprisingly, was not infected with any of the virus species (Table 3 ).

\section{DISCUSSION}

A systematic survey on the distribution of these six species at a national level has never been reported. The occurrence and the prevalence of six species of the garlic virus complex (OYDV, LYSV, GarCLV, GarV-C, GarV-D and GarMbFV) reported to occur in Brazil was studied in the main growing regions cultivated under different agricultural production systems using species-specific RTPCR technique

In Brazil, species of the genus Potyvirus are widespread across all growing areas, regardless the production system and cultivar. Differently from what is generally reported worldwide, LYSV prevailed over the other species and not OYDV. Similar data was found in Japan, with dispersion of LYSV in seven growing areas at a frequency from $73 \%$ to $100 \%$, while the OYDV's dispersion ranged from $0 \%$ to $40 \%$ (Takaichi et al., 1998). These results differ from the analyses performed in several other countries around the world in which the OYDV prevailed over LYSV (Barg et al., 1994; Lot et al., 1998; Dovas et al., 2001; Cafrune et al., 2006; Shaareen et al., 2008).

A higher prevalence of LYSV does not necessarily indicate that the damage caused by this species is greater than that caused by OYDV. Lot et al. (1998) found that single infections of LYSV caused a reduction in bulb weight from $17 \%$ to $28 \%$ in the cvs. Messidrome and Germidour. However, single infections of OYDV reduced $65 \%$ and $48 \%$ of bulb weight in the cvs. Messidrome and Germidour, respectively. Mixed infections with OYDV and LYDV had a synergistic effect for those cultivars with bulb weight reduced from $56 \%$ to $84 \%$. It is assumed that significant damages might be occurring in VNGSP and CG, in which LYSV prevalence was higher and mixed infections with potyvirus and allexivirus species occurred.

VNGSG is being used for some years at Chapada Diamantina (Bahia) (Melo et al., 2011, and is being implemented in Francisco Sá (Minas Gerais), where CG is the main system used. These growers traditionally use garlicseed with lower quality than growers that adopt the other systems. This can lead to an increased rate of reinfection every cultivation cycle. As the planting of the seeds from

TABLE 3 - Prevalence of virus species per garlic cultivars and agricultural production system

\begin{tabular}{llcccccc}
\hline \hline \multirow{2}{*}{ Cultivar } & \multirow{2}{*}{ Production System } & \multicolumn{5}{c}{ Virus Prevalence (\%) } \\
\cline { 3 - 7 } & & OYDV $^{2}$ & LYSV & GarCLV & GarV-C & GarV-D & GarMbFV \\
\hline Amarante & VFCG & 17 & 34 & 0 & 7 & 14 & 7 \\
Caçador & NVNGSG & 14 & 86 & 0 & 86 & 0 & 0 \\
Caçador & VNGMG & 7 & 52 & 0 & 0 & 0 & 11 \\
Caçador & VNGSG & 13 & 87 & 10 & 15 & 0 & 0 \\
Cateto Roxo & CG & 50 & 63 & 23 & 47 & 0 & 50 \\
Cateto Roxo & VFCG & 13 & 17 & 3 & 36 & 8 & 23 \\
Chonan & NVNGSG & 0 & 29 & 29 & 14 & 0 & 0 \\
Chonan & VNGMG & 0 & 68 & 0 & 8 & 0 & 8 \\
Jonas & VNGMG & 0 & 50 & 17 & 0 & 0 & 0 \\
Quitéria & NVNGSG & 0 & 29 & 0 & 0 & 0 & 0 \\
Quitéria & VNGMG & 6 & 38 & 19 & 0 & 0 & 0 \\
São Valentino & VNGMG & 0 & 0 & 0 & 0 & 0 \\
\hline
\end{tabular}

${ }^{1}$ Vernalized Noble Garlic Major Grower (VNGMG). Vernalized Noble Garlic Small Grower (VNGSG). Non Vernalized Noble Garlic Small Grower (NVNGSG). Virus-Free Common Garlic (VFCG). Traditional Common Garlic (CG). Total: Number of infected samples/total number of samples per production system. ${ }^{2}$ Onion yellow dwarf virus (OYDV), Leek yellow stripe virus (LYSV), Garlic common latent virus (GarCLV), Garlic virus C (GarV-C), Garlic virus D (GarV-D), Garlic mite-borne filamentous virus (GarMbFV). 
Spread of virus species in garlic fields cultivated under different agricultural production...

the two systems occurs simultaneously, the noble cultivar's reinfection level does happen as in CG. Due to the low technological input adopted by these growers, high initial inoculum rate in the propagative material used is expected. This assumption was also analyzed in this study, since in both CG and VNGSG, LYSV was highly prevalent, and in samples from these production systems mixed infections usually occurred, which, for its synergistic effect, may cause an increase in the intensity of the damage caused by the virus complex (Taiwo et al., 2007).

The carlavirus GarCLV is spread across several regions around the world. However, it is not endemic (Barg et al., 1994; Barg et al., 1997). In single infections, carlaviruses causes no severe symptoms in the infected plants (Bellardi et al., 1995). However, mixed infections of carlavirus and potyvirus species may have a synergistic effect on symptoms (Takaichi et al., 1998).

The prevalence rates of GarCLV were lower in the four production systems in comparison to the allexiviruses. However, in the samples GO6, GO5 (data not show) and MG21, BA28 and BA27, in which GarCLV was detected, it was possible to detect mixed infection with potyvirus or allexivirus species The prevalence of potyviruses was two times higher than for GarCLV (Table 2), probably due to the more effective aphid transmission of potyviruses compared to carlaviruses (Van Dijk, 1993).

Allexivirus species occurred mostly in multiple infections with an irregular prevalence ranging from 0 to $93 \%$. GarV-C was detected in all production systems and, in samples from VFCG and CG, in high prevalence rates reaching over $90 \%$. GarV-D only occurred in VFCG compared to GarMbFV that had an uneven spread among the systems, reaching its highest prevalence rates in CG system. The irregular distribution of allexivirus species was also observed in Greece (Dovas et al., 2001). However, in South Korea, Allexivirus was the most abundant of all the three genera of the virus complex. It was spread in all growing areas of that country (Koo et al., 2002). The uneven distribution of allexiviruses may be related to its dissemination during the storage of the bulbs, where mites are more favorable to transmit these viruses than under field conditions (Mann \& Minges, 1958). However, an appropriate storage prevents the occurrence of mites and, consequently, the transmission of allexiviruses. Therefore, if the growers are to produce their own planting material which very often happens - and inadequately store it, high rates of allexivirus infection might occur in the next planting due to mite infestations (Dovas et al., 2001). Another factor which could help to spread these viruses, especially in VFCG, would be the mite infestation under the greenhouse conditions used to produce the virus-free cloves, that favors mite proliferation if not properly controlled.

More than one allexivirus were simultaneously detected and also in multiple infections with potyviruses. A similar situation was reported by Koo et al. (2002), Lu et al. (2008), Takaichi et al. (1998) and Takaichi et al. (2001), and they suggested that these allexivirus multiple infections may increase symptoms and cause a decrease in production.

Besides the widely distribution of viral species, distribution of viral species in the mainly grown cultivar was also studied. It was not possible to state whether a particular cultivar is more susceptible to a certain viral species since a previous analysis of the health status of the material that originated the bulbs studied was not carried out. Virus species distribution among the cultivars was also uneven, regardless the production system. At least one species was detected in all of them. For cv. Cateto Roxo grown under $\mathrm{CG}$, for example, species of all three genera were detected with prevalence rates higher than the ones from VFCG. In VFCG, infection naturally occurred as the garlic was exposed under field conditions, but it happens with slow reinfection rates (Melo Filho et al., 2004). In regions in which CG is the mostly adopted growing system, growers usually select the best produced bulbs for the market leaving the worst to be used as seed for the next year. This procedure results in garlic plants with high infection levels, leading to a decrease in both yield and health status of the propagation material.

Altogether, comparing all virus species analyzed, noble garlic cultivars had lower infection rates in regions where the production system was NVNGSG, in comparison to VNGMG. This could be explained by the health status of the original seed used by farmers. The growers from Flores da Cunha (Rio Grande do Sul) report that seed which is planted in that region came from Farroupilha (Rio Grande do Sul) and is being used for more than 10 years in successive crops. But, at the same time, the noble garlic-seeds used at VNGMG (Cristalina, Goiás) come from Santa Catarina State and is probably multiplied under field conditions for two to three years at most, which suggests that this seed have a same health status or lower than the seed used in Flores da Cunha.

Among the cultivars used in VNGMG, the ones use at São Gotardo (Minas Gerais) stood out for their lower virus prevalence or no virus infection at all, as for cv. São Valentino. The material provided for analysis had good health status and its field reinfection rates were small. On the other hand, at Francisco de Sá (Minas Gerais) all virus species could be detected, which might be associated to lower technological input production system adopted in that region.

In general, cultivation systems directly influenced the quality of the propagation material. In VNGMG and NVNGSG, in which there is a high technological input, less virus infections were found, in contrast to CG, VFCG and VNGSG, in which most virus species occurred. CG is being gradually replaced by VFCG and VNGSG, thus increasing the technological level in regions where the main garlic cultivars used are rustic. However, it is necessary for the garlic growers to become aware of the importance of the health status of the seed. Such substitution program is being conducted by the Embrapa Vegetables team since 2002 and 
the changes in the assisted areas are already noticeable. The samples BA29, BA13, BA10 and BA25 from VFCG (starting from virus free cloves) had virus prevalence rates less than $25 \%$ in their materials.

Based on these results, it is possible to draw a map of the distribution of the garlic virus species complex per production system for the main growing areas in Brazil. New surveys involving a larger number of samples and growing areas, including novel reported virus species must be conducted with a broader sampling design to determine the species incidence in the samples. This study should be complemented with other approaches to also evaluate the damages caused by solely or mixed infection with garlicvirus species. The broad distribution and occurrence of garlic viruses in all studied regions reinforce the need of a garlic-seed certification program in Brazil, which is essential to improve the health conditions of the crop. Thus, it will be possible to develop joint actions with different actors in the production process aiming at reducing the losses caused by the garlic virus complex in the garlic producing regions of the country.

\section{ACKNOWLEDGEMENTS}

This work was partially funded by Coordenação de Aperfeiçoamento de Pessoal de Nível Superior - CAPES, Conselho Nacional de Desenvolvimento Científico e Tecnológico - CNPq e FAP-DF, Brazil. We thank Dr. Francisco Aragão (Embrapa Recursos Genéticos and Biotecnologia) and Dr. Bergmann Ribeiro (Universidade de Brasília) for providing us the primer pairs EF1 and T1, respectively. We also thank the garlic growers for sending us samples for this work and Embrapa Hortaliças for the garlic virus-free seeds. Renato Oliveira Resende is a CNPq research fellow.

\section{REFERENCES}

Abreu EFM, Aragão FJL (2007) Isolation and characterization of a myo-inositol-1-phosphate synthase gene from yellow passion fruit (Passiflora edulis f. flavicarpa) expressed during seed development and environmental stress. Annals of Botany 99:285-292.

Barg EL, Vetten HJ, Green SK (1994) Identification, partial characterisation and distribuition of viruses infecting Allium crops in south and south-east Asia. Acta Horticulturae 358:251-258.

Barg EL de, Vetten HJ, Green SK (1997) Viruses of alliums and their distribuition in different Allium crops and geographical regions. Acta Horticulturae 433:607-616.

Bellardi MG, Marani F, Betti L, Rabiti AL (1995) Detection of Garlic common latent virus (GCLV) in Allium sativum L. in Italy. Phytopathology 34:58-61.

Cafrune EE, Perotto MC, Conci VC (2006) Effect of two Allexivirus isolates on garlic yield. Plant Disease 90:898-904.

Dovas IC, Hatziloukas E, Salomon R, Barg E, Shiboleth Y \& Nikolaos IK (2001) Incidence of viruses infecting Allium spp. in
Greece. European Journal of Plant Pathology 107:677-684.

Dusi AN (1995) Doenças causadas por vírus em alho. Informe Agropecuário 17:19-21.

Fajardo TVM, Nishijima M, Buso JA, Torres AC, Ávila AC, Resende RO (2001) Garlic viral complex: Identification of potyviruses and carlaviruses in Central Brazil. Fitopatologia Brasileira 26:619-626.

IBGE (Instituto Brasileiro de Geografia e Estatística), http:/ www.ibge.net/home/estatística/economia/pam/tabela/1 pam.shtm. Accessed on September 10, 2009.

Koo BJ, Kang SC, Chang MU (2002) Survey of garlic vírus disease and phylogenetic characterization of garlic viruses of genus Allexivirus isolated in Korea. Journal of Plant Pathology $18: 237-243$

Lot H, Chovelon V, Souche S, Delecolle B (1998) Effects of onion yellow dwarf and leek yellow stripe viruses on symptomatology and yield loss of three French garlic cultivars. Plant Disease 82:1381-1385.

Lu YW, Chen HY, Adams MJ, Chen JP (2008) Serological relationships among the over-expressed coat proteins of allexiviruses. Journal of Phytopathology 156:251-255.

Mann LK, Minges PA (1958) Growth and bulbing of garlic (Allium sativum $\mathrm{L}$.) in response to storage temperature of planting day length and planting date. Hilgardia 27:385-419.

Melo-Filho PA, Nagata T, Dusi AN, Buso JA Torres AC, Eiras M, Resende RO (2004) Detection of three Allexivirus species infecting garlic in Brazil. Pesquisa Agropecuária Brasileira 39:375-340.

Melo-Filho PA, Resende RO, Cordeiro CMT, Buso JA, Torres AC, Dusi AN (2006). Viral reinfection affecting bulb production in garlic after seven years of cultivation under field conditions. European Journal of Plant Pathology 116:95-101.

Melo WF, Resende FV, Guiducci-Filho E, Dusi AN (2011). Da bancada ao agricultor: a transferência da tecnologia de alho livre de vírus aos agricultores familiares da Bahia. Cadernos de Ciência \& Tecnologia 28:81-114.

Mituti J, Marubayashi M, Moura MF, Krause-Sakate R, Pavan M (2011) First report of Shallot latent virus in garlic in Brazil. Plant Disease 95:227.

Nunes ACS, Vianna GR, Cuneo F, Maya-Farfa JE, Capdeville G, Rech E, Aragão FJL (2006) RNAi-mediated silencing of the myoinositol-1-phosphate synthase gene (GmMIPS1) in transgenic soybean inhibited seed. Planta 224:125-132.

Rodrigues JCM, Souza, ML, O'Reilly D, Velloso LM, Pinedo FJR, Razuck FB, Ribeiro B, Ribeiro BM (2001) Characterization of the ecdysteroid UDP-glucosyltransferase (egt) gene of Anticarsia gemmatalis nucleopolyhedrovirus. Virus Genes 22:103-112.

Shahraeen N, Lesemann DE, Ghotbi T (2008) Survey for viruses infecting onion, garlic and leek crops in Iran. Bulletin OEPP/EPPO 38:131-135.

Sumi S, Tsuneyoshi T, Fututani H (1993) Novel rod-shaped viruses isolated from garlic, Allium sativum, possessing a unique genome organization. Journal of General Virology 74:1879-1885.

Takaichi M, Yamamoto M, Nagakubo T, Oeda K (1998) Four garlic viruses identification by reverse transcripition- polymerase chain reaction and their regional distribution in northern Japan. Plant Disease 82:694-698. 
Takaichi M, Nagakubo T, Oeda K (2001) Mixed virus infection of garlic determination by multivalent polyclonal antiserum and virus effects on disease symptoms. Plant Disease 85:71-75.

Taiwo AM, Kareem KT, Nsa IY, Hughes DAJ (2007) Cowpea viruses: Effect of single and mixed infections on symptomatology and virus concentration. Virology Journal 4:95.

Van Dijk P (1993) Survey and characterization of potyviruses and their astrains of Allium species. Netherlands Journal of Plant Pathology 99:1-48.

Yamashita K, Sakai, J, Hanada, K (1996) Charactherization of a new virus garlic (Allium sativum L.), garlic mite-borne mosaic virus. Annals of the Phytopathological Society of Japan 62:483489.

TPP 359 - Received 21 July 2011 - Accepted 6 January 2012

Section Editor: F. Murilo Zerbini 